\title{
CHARACTERISTIC OF THE ISOLATE BEAN YELLOW MOSAIC VIRUS ISOLATED FROM YELLOW LUPINE
}

\author{
O. V. Pyrih, O. O. Dmytruk, T. O. Bova \\ Institute of Agricultural Microbiology and Agroindustrial Manufacture, NAAS \\ 97, Shevchenka str., Chernihiv, 14027, Ukraine; e-mail: altrockman@mail.ru
}

The comparative characteristic of biological, physical and chemical, and antigenic properties of the isolate bean yellow mosaic virus (BYMV) isolated from yellow lupine on the Chernihiv region territory. It is found that properties of $B Y M V$-P isolate differ from the typical properties of strain $B Y M V(B-25)$ and isolates studied in Ukraine.

Key words: yellow lupine, bean yellow mosaic virus (BYMV), isolate, antiserum.

Among various plant diseases, viral infections are one of the limiting factors reducing crop productivity and marketability and deteriorating product quality. In Ukraine agrocenoses, among phytopathogenic viruses that can cause diseases of yellow lupine, the most common and economically important is bean yellow mosaic virus (BYMV, Potyviridae family, Potyvirus genus) $[1 ; 2]$.

Unlike other pathogens, virus persists in the infected plant throughout its life, as well as in its generative progeny, which leads to the accumulation of viruses in seed and in agrocenoses. Yield losses due to viral lesion depend on the species and strains of pathogens common for this soil-climatic zone, genetically determined varietal susceptibility to infection and growing conditions. Involvement of lupine yellow crop with bean yellow mosaic virus, especially of late varieties, may be 50 to $90 \%$ [3]. Reduced productivity of lupine plants affected with BYMV is determined by the phase of their development at the time of infection. With the involvement of yellow lupine plants in the rosellate phase, crop losses reach $95 \%$, and in the budding to early flowering phase - $56 \%$ [4].

Mantioned above virological situation demonstrates the need for special attention to control diseases induced by bean yellow mosaic virus in the virological monitoring system of agrocenoses.

BYMV detection agrocenoses of yellow lupine and investigation of its properties is important for ensuring effective control of viral diseases at all stages of growing varieties, de- velopment of diagnostic tools and measures to control this pathogen.

The aim of our work was to detect, identify and investigate biological, physical and chemical, and antigenic properties of BYMV (isolate Progresyvnyi (Progressive), BYMV-P) isolated from yellow lupine in Chernihiv region.

Materials and methods. To confirm viral aetiology of the detected disease, identification of its pathogen, complex of the following diagnostic methods was applied: symptomatology, biotesting, electron microscopy, polymerase chain reaction [5-11].

Biological and physical and chemical properties of isolate BYMV-P (size of viral particles, thermal inactivation point (TIP), limiting juice dilution (LJD), infectivity persistence (IPI), molecular weight of capsid protein) was determined using appropriate methods [12-15], comparing them with the properties of a typical strain of BYMV (B-25) and isolates studied in Ukraine [16; 17].

To investigate the antigenic properties, BYMV-P isolate was accumulated on the indicator plants Vicia faba, which were grown under conditions of vegetation room at $20-25{ }^{\circ} \mathrm{C}$ and photoperiod of 16 hours. Leaves of infected plants were sampled at day 14-21 after inoculation, at the period of maximum viral concentration $[18 ; 19]$.

Obtaining of purified preparations of bean yellow mosaic virus to immunize rabbits and to receive further anti-BYMV antiserum, was conducted using the method of deposition with polyethylene glycol (PEG) [20], differential cen- 
trifugation, preparative electrophoresis [21;22].

Control of stages of obtaining pure preparations of BYMV was performed by electron microscopy method with native preparations, enhanced with $2 \%$ phosphotungstic acid solution. Preparations were tested in electron microscopes Tesla-540 and EM-125 with instrumental magnification of 20 thousand. [23].

The purity and concentration of BYMV viral preparations was measured by spectrophotometry [24].

Rabbit antiserum obtained after immunization of animals with BYMV preparations according to the generally accepted scheme of three injections at intervals of 7 days [25]: the first immunization - subcutaneously with complete Freund's adjuvant (Sigma, USA), the second one - intradermally to 5-6 points along spinal column and third - subcutaneously with MONTANIDE ISA 25 adjuvant (SEPPIC, France). In a week after the last immunization, blood was sampled for three times from marginal auricular vein, and titre of serum was measured in the drop agglutination test [26].

Results and discussion. According to the result of phytoviral monitoring of yellow lupine crops, plants with symptoms characteristic for BYMV were found: typical narrow leaves, mosaic, leaf deformation and their reduction, as well as the formation of dark green bubble spots of various sizes (Fig. 1).

Electron microscopic analysis of infected plant material showed the presence of viral particles in preparations, corresponding to BYMV in morphology and size (750-755 nm) (Fig. 2).

Study of ultrathin slices of yellow lupine leaves infected with BYMV, with clear symptoms of involvement allowed to identify virus specific inclusions (Edvardson structures), which is a characteristic feature of potiviral infection (Fig. 3). The results obtained at the cellular level add data that indicate intense BYMV deve-
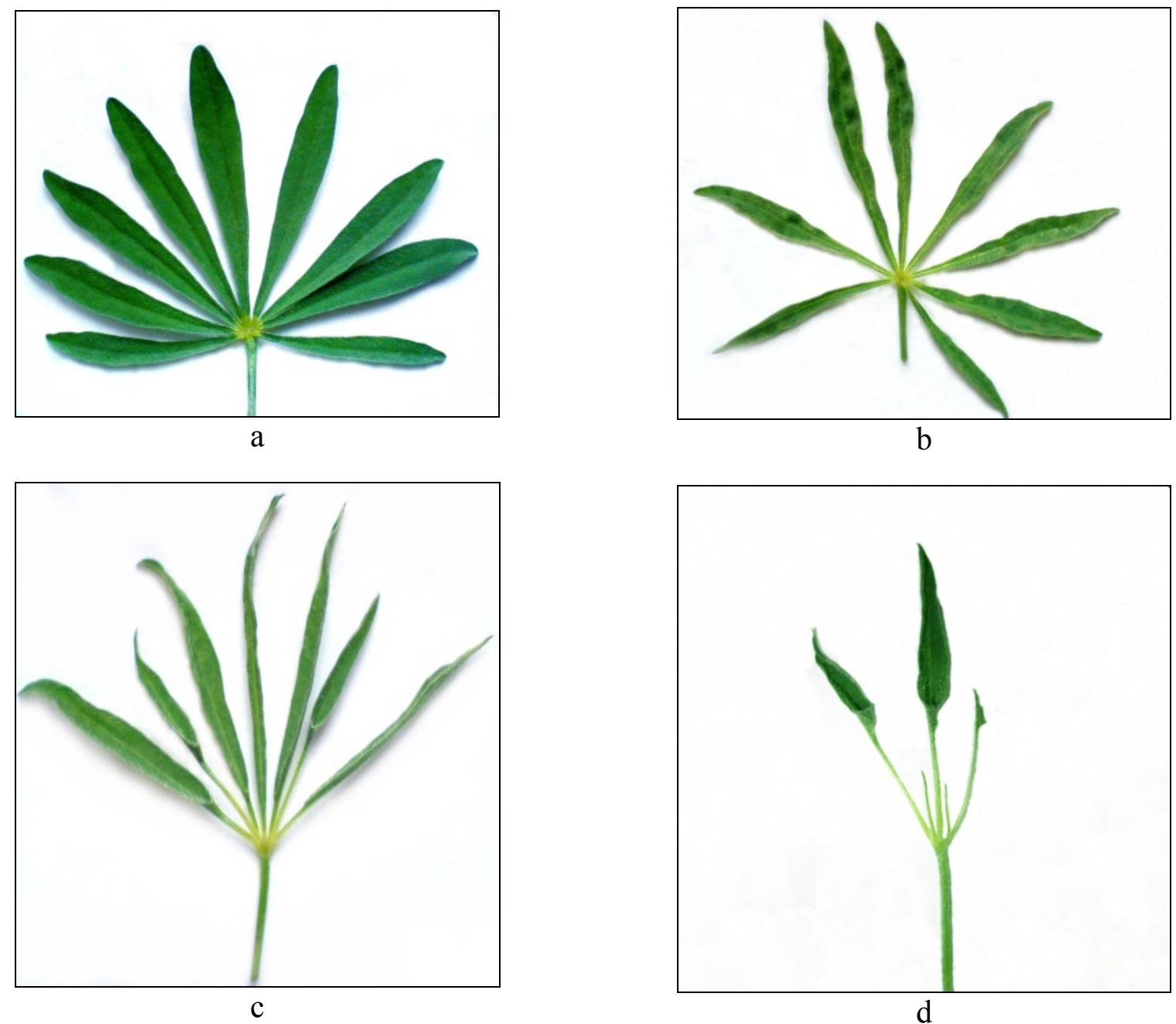

Fig. 1. Symptoms of BYMV on the leaves of Progresyvnyi variety of yellow lupine: a - leaf of the health plant; $b, c, d$-narrow leaves accompanied with mosaic, deformation and reduction of the leaves. 


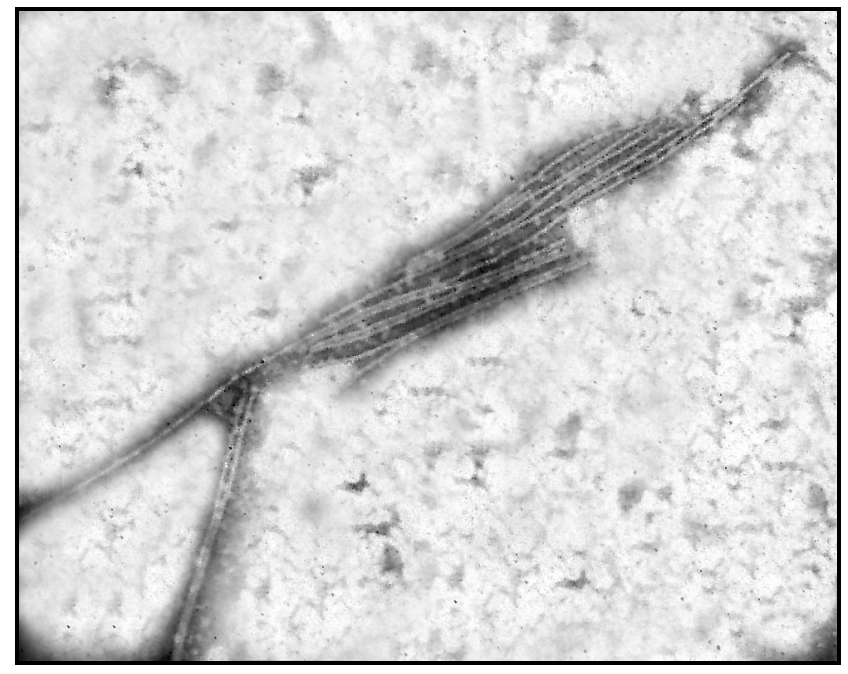

Fig. 2. Electron diffraction pattern of bean yellow mosaic virus, instrumental magnification $\times 20000$.

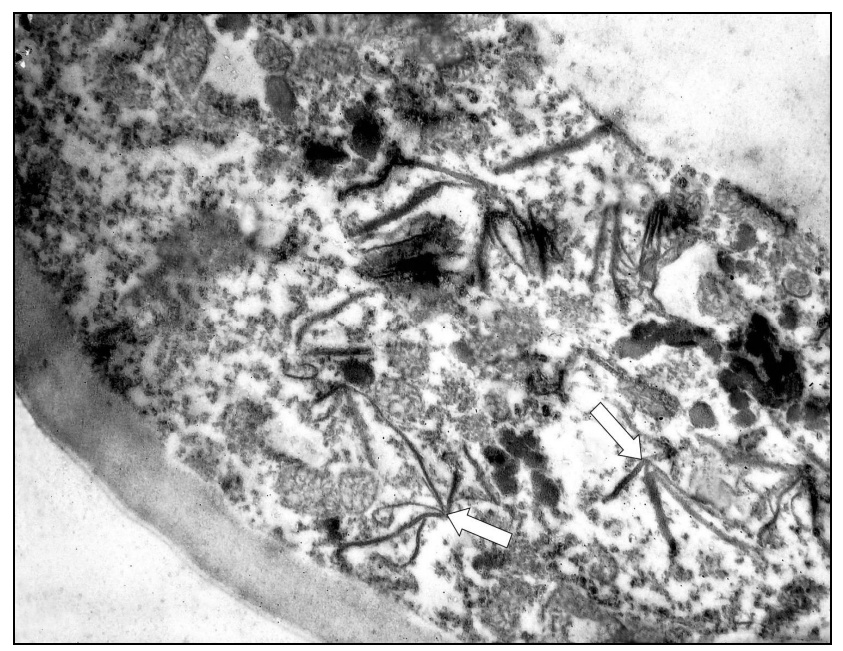

Fig. 3. Ultrathin slices of Lupinus luteus $L$. Leaf cell infected with BYMV - virus induced inclusions (Edvardson structures), instrumental magnification $\times 22000$.

lopment in lupine plants and allow to identify the agent of studied disease as bean yellow mosaic virus.

To confirm the presence of the pathogen inducing narrow leaves in yellow lupine plants, BYMV identification in the samples of test plants Vicia faba L. by polymerase chain reaction (PCR) was conducted at the National University of Bioresources and Environmental Management of Ukraine. According to the results of PCR analysis of samples, the presence of amplification bands of the expected size (266 bp) was detected; and this shows the presence of BYMV in plants (Fig. 4). No nonspecific bands of amplification products were

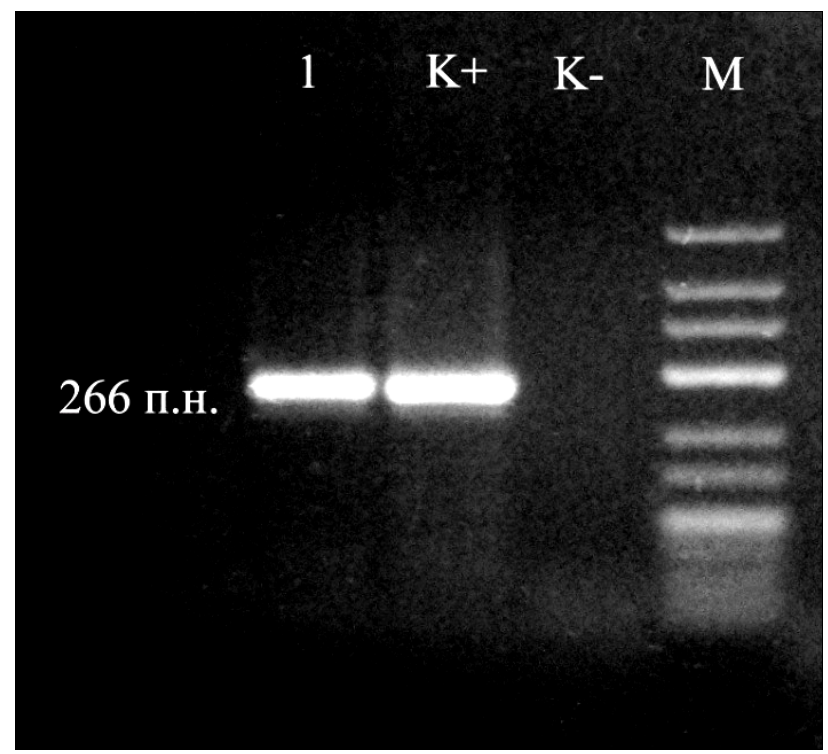

Fig. 4. Electrophoregram of PCR products during determination of bean yellow mosaic virus: 1 - analyzed sample; $K(+)$ - positive control; $K(-)$ - negative control; $M-$ marker of fragment length (base pairs).

found on electron differentiation patterns.

Thus, according to the results of phytovirusological examination, electron microscopic diagnostics and PCR analysis of the samples of Progresyvnyi variety of yellow lupine at the territory of Chernihiv region, isolation of BYMV-P was performed.

Characteristics of the biological, physical and chemical, and antigenic properties isolate BYMV-P was investigated comparing it with the typical strain BYMV (B-25) and isolates obtained in Ukraine.

Biotesting of obtained isolate BYMV-P was performed on the indicator plants Vicia faba L., Pisum sativum L., Phaseolus vulgaris L. Upon inoculation of the test plants with BYMV-P isolate, manifestation of different symptoms of infection were observed. It was established that the studied isolate differs from the typical strain BYMV (B-25) (Table 1). In particular, in the plants of Vicia faba L. virus caused a pronounced dark green systemic mosaic and deformation of leaf plate (Fig. 5a), but did not form chlorotic symptoms. In the test plants Pisum sativum L., BYMV-P isolate caused systemic mosaic (Fig. 5b), but did not induce necrotization of the tip, which is characteristic of a typical strain. In plants Phaseolus vulgaris L., studied isolate induced symptoms similar for typical strain, but did not cause spotting. 
Table 1. Response of the test plants to the infection with BYMV-P viral isolate and BYMV typical strain (B-25)

\begin{tabular}{|l|l|l|}
\hline \multirow{2}{*}{ Test plant } & \multicolumn{2}{|c|}{ Characteristic viral symptoms } \\
\cline { 2 - 3 } Vicia faba L. & $\begin{array}{l}|c| \\
\text { BYMV-P } \\
\text { mosaic, deformation of leaf plate }\end{array}$ & $\begin{array}{l}\text { Chlorosis of the ribs, yellow-green } \\
\text { spotting, corrugate and deformed } \\
\text { leaf plate, systemic expansion. }\end{array}$ \\
\hline Pisum sativum L. & Systemic mosaic & $\begin{array}{l}\text { Necrotization of the tip, systemic } \\
\text { mosaic }\end{array}$ \\
\hline Phaseolu vulgaris L. & $\begin{array}{l}\text { Systemic yellow mosaic, } \\
\text { necrotization of the leaves }\end{array}$ & $\begin{array}{l}\text { Spotting, necrotization of the tip, } \\
\text { systemic mosaic. }\end{array}$ \\
\hline
\end{tabular}

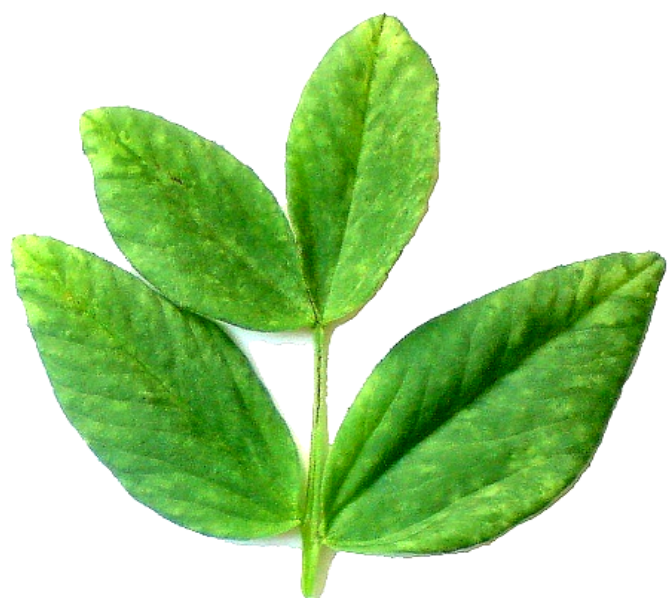

a

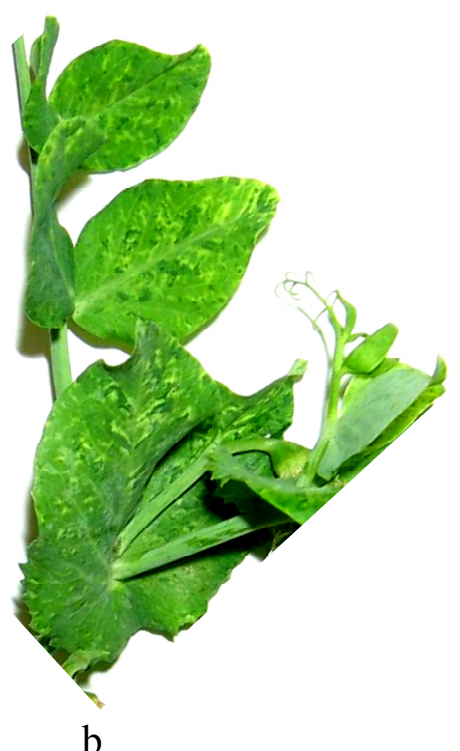

Fig. 5. Symptoms of BYMV infection on Vicia faba L. (a) and Pisum sativum L. (b) plants.

It is known that one of the characteristics of the virus that correlates with the biological properties of the strain is its thermal stability. In the study of the physical properties of BYMV-P isolate, it was found that the virus is quite resistant to high temperatures. The juice from the leaves of test plants Vicia faba L. retained infectious properties at $+74{ }^{\circ} \mathrm{C}$ and lost them at $+76{ }^{\circ} \mathrm{C}$ (Table 2) (for comparison: thermal inactivation point of the typical strain BYMV (B-25) is $+65^{\circ} \mathrm{C}$, and of isolate BYMV-P obtained from soybean in the Kyiv region is $+70^{\circ} \mathrm{C}$ ).

During investigation of the infectivity of various dilutions of the juice of Vicia faba L., limiting juice dilution, without loss of viral infectivity, was $10^{-4}-10^{-5}$ (LJD of BYMV typical strain (B-25) $-10^{-3}-10^{-4}$, isolate BYMV-P $\left.10^{-4}\right)$.
At room temperature, the virus retained infectivity in the juice of infected bean plants during 3 days, while the typical strain B-25 and isolate BYMV-P remain infectious for $2-7$ and 2-3 days, respectively.

PAGE analysis of viral protein component showed the presence of BYMV-P polypeptide with $\mathrm{M}_{\mathrm{r}} 32 \mathrm{kDa}$ in preparations, which corresponds to the weight of capsid protein that is characteristic for this virus and at the same time, slightly differs from the weight of the protein component of the viral particles of other isolates and typical strain BYMV (Mr of capsid protein of the typical strain BYMV (B-25) is 33$35 \mathrm{kDa}, \mathrm{BYMV}-\mathrm{P}$ isolate is $34 \mathrm{kDa}$ ).

It is assumed that the length of BYMV particles is $750 \mathrm{~nm}$, but it can vary from 700 to $770 \mathrm{~nm}$, depending on the strain and the method of preparation obtaining. As have been noted in 
Table 2. Physical and chemical properties of BYMV viral isolates

\begin{tabular}{|c|c|c|c|c|c|c|}
\hline BYMV isolates & $\mathrm{TIP},{ }^{\circ} \mathrm{C}$ & LJD & IP, days & $\begin{array}{c}\text { Particle } \\
\text { length, } \mathrm{nm}\end{array}$ & $\begin{array}{l}\mathrm{M}_{\mathrm{r}} \text { of capsid } \\
\text { protein, } \mathrm{kDa}\end{array}$ & Author, year \\
\hline $\begin{array}{l}\text { Studied BYMV-P iso- } \\
\text { late obtained from } \\
\text { yellow lupine }\end{array}$ & 76 & $10^{-3}-10^{-4}$ & 3 & $750-755$ & 32 & $\begin{array}{c}\text { Pyrih, } \\
\text { Kolomiiets, } \\
\text { Dmytruk, } \\
\text { Mamchur, } \\
2010\end{array}$ \\
\hline $\begin{array}{c}\text { BYMV-P isolate ob- } \\
\text { tained from soybean } \\
\text { plants }\end{array}$ & 70 & $10^{-4}$ & $2-3$ & 750 & 34 & $\begin{array}{c}\text { Kyrychenko, } \\
\text { Kovalenko, } \\
\text { Kraieva, 2010 }\end{array}$ \\
\hline $\begin{array}{l}\text { Isolate I obtained } \\
\text { from lupine }\end{array}$ & $55-60$ & $1: 800$ & 3 & $755-760$ & 33.4 & \multirow{2}{*}{$\begin{array}{c}\text { Zhmurko, } \\
\text { Molchanets, } \\
\text { Porembska, } \\
1989\end{array}$} \\
\hline $\begin{array}{l}\text { Isolate II obtained } \\
\text { from lupine }\end{array}$ & $60-65$ & $1: 2000$ & 2 & 770 & 36.9 & \\
\hline $\begin{array}{c}\text { Typical strain } \\
\text { B-25 }\end{array}$ & 65 & $10^{-3}-10^{-4}$ & $2-7$ & 750 & $33-35$ & $\begin{array}{c}\text { ICTV } \\
57.0 .1 .0 .009\end{array}$ \\
\hline
\end{tabular}

our studies, electron microscopic analysis of the infected plant material showed the presence of BYMV particles in the preparations of 750 $755 \mathrm{~nm}$ in size, under the length of particles of BYMV strain B-25 and BYMV-P isolate of $750 \mathrm{~nm}$.

As a result of conducted work, we obtained purified preparations of BYMV-P, that are characterized by UV absorption spectrum typical for potiviruses, with minimal absorption at 245 $247 \mathrm{~nm}$ and maximal one at 260-265 nm, $\mathrm{E}_{260} / \mathrm{E}_{280}$ ratio was 1.21 . Viral preparations were well purified, concentration of protein in them was $2.9-7.8 \mathrm{mg} / \mathrm{mL}$ (Table 3 ).

Immunization of rabbits with purified BYMV preparations allowed to obtain hyperimmune serum that provides drop agglutination test with BYMV infected plants using material diluted in the ratio of $1: 512$. Antiserum is specific and does not react with extracts from health lupine and bean plants.

Therefore, application of the range of diagnostic methods allowed to find and identify bean yellow mosaic virus in yellow lupine plans. During investigation of biological, physical and chemical, and antigenic properties of BYMV-P isolate, its difference from the properties of the typical strain B-25 and isolates obtained and studied in Ukraine was proved.

1. Головченко О. В. Аналіз ознак люпину, пов'язаних із стійкістю до вірусу жовтої мозаїки квасолі : автореф. дис. ... канд. біол. наук : 03.00.21 - фітопатологія / О. В. Головченко. K., 1996. - $24 \mathrm{c}$.

2. Проскура И. П. Люпин / Проскура И. П., Валовненко Д. К, Романенко В. И. - К. : Урожай, 1979. - 144 с.

3. Корнейчук Н. С. Грибные болезни люпинов / Н. С. Корнейчук. - К. : Колобиг, 2010. $376 \mathrm{c}$.

4. Порембская Н. Б. Вирусные болезни люпина : автореф. дис. ... канд. с.-х. наук / Н. Б. Порембская. - Л., 1965. — 22 с.

5. Шмидт Э. Вирусные болезни люпина и создание устойчивых форм для селекции / Э. Шмидт, Д. Шпаар // Вестн. с.-х. науки. - М. : Колос, 1981. — № 9. — С. 32-43.

Table 3 Characteristics of BYMV-P antigen

\begin{tabular}{|c|c|c|c|c|}
\hline \multirow{2}{*}{ Viral antigen } & \multicolumn{2}{|c|}{ Optical density, AU } & \multirow{2}{*}{$\begin{array}{c}\text { Ag concentration, } \\
\mathrm{mg} / \mathrm{mL}\end{array}$} & $\mathrm{E}_{260} / \mathrm{E}_{280}$ ratio \\
\cline { 2 - 3 } & $260 \mathrm{~nm}$ & $280 \mathrm{~nm}$ & 7.8 & 1.24 \\
\hline BYMV-1 & 1.607 & 1.295 & 4.3 & 1.19 \\
\hline BYMV-2 & 0.795 & 0.666 & 2.9 & 1.2 \\
\hline BYMV-3 & 0.536 & 0.446 & \\
\hline
\end{tabular}


6. Віруси і вірусні хвороби бобових культур / [С. М. Московець, В. Г. Краєв, Н. Б. Порембська та ін.]. - К. : Наукова думка, 1971. — 136 с.

7. Horvath J. Host plants in diagnosis / J. Horvath // Diagnosis of plant virus diseases / ed. by R. E. F. Matthews. - Boca Raton, Florida, USA : CRC Press, 1993. - P. 15-48.

8. Карупу В. Я. Электронная микроскопия / В. Я. Карупу. - К. : Вища школа, 1984. - 208 с.

9. Бужоряну В. В. Ультраструктура растительной клетки при вирусной инфекции / В. В. Бужоряну, Б. Т. Матиенко. - Кишинев, 1986. $153 \mathrm{c}$.

10. Полімеразна ланцюгова реакція у практиці ветеринарної медицини та біологічних дослідженнях / [Стегній Б. Т., Герілович А. П., Лиманська Щ. Ю. та ін.]. - Харків : НТМТ, 2010. - 228 c.

11. Антіпов І. О. ПЛР діагностика вірусу жовтої мозаїки квасолі / І. О. Антіпов // Науковий вісник НУБіП України. Серія : біологія, біотехнологія, екологія. - 2014. - Вип. 204. C. 151-154.

12. Степаненко В. И. Некоторые вопросы идентификации штаммов фитопатогенных вирусов с помощью электронной микроскопии / В. И. Степаненко // Штаммы вирусов растений. - Владивосток : ДВНЦ АН СССР, 1977. C. 253-261.

13. Brandes J. Indentifizierung von gestrecten pflanzenpathogenen viren auf morphologischer Grundlage / J. Brandes // Mitt. Biol. Bundersanst. 1964. - P. 110-130.

14. Hill S. A. Methods in Plant Virology / S. A. Hill. - Oxford, Great Britain : Alden Press, 1984. $-167 \mathrm{p}$.

15. Laemmli U. K. Cleavage of structural proteins during assembly of the head of bacteriophage T4 / U. K. Laemmli // Nature. — 1970. — № 15. P. 608-685.

16. ICTVdB : Bean yellow mosaic virus [електронний ресурс] / ed. by Buchen-Osmond C. New York, USA : Columbia University, 2006. Version 4. - Режим доступу : http://ictvdb.biomirror.cn/ICTVdB/00.057.0.01.009.htm.
17. Кириченко А. Н. Характеристика вируса желтой мозаики фасоли, выделенного из сои / А. Н. Кириченко // Микробиологический журнал. - 2013. - Т. 75, № 3. - С. 68-73.

18. Yarwood C. E. Mechanical transmission of plant viruses / C. E. Yarwood // Adv. Virus Res. 1957. - Vol. 4. - P. 243-278.

19. Попкова К. В. Практикум по иммунитету растений / К. В. Попкова, 3. П. Качалова. - М. : Колос, 1984. - 176 c.

20. Метод получения препарата Y-вируса картофеля и приготовление диагностических антисывороток / [В. К. Новиков, И. Г. Атабеков, М. О. Агур и др.] // Сельскохоз. биология. 1982. — Т. 17, № 5. - С. 706-711.

21. Остерман Л. А. Методы исследования белков и нуклеиновых кислот: электрофорез и ультрацентрифугирование : [практ. пособие] / Л. А. Остерман. - М. : Наука, 1981. - 288 с.

22. Пат. 64377А Україна, МПК С 12 N 7/00, С 12 M 3/00. Пристрій для препаративного електрофорезу в гранульованому середовищі / Мамчур О. Є., Дмитрук О. О., Зарицький М. М. ; заявник і патентовласник Інститут сільськогосподарської мікробіології УААН. - № 2003054637, заявл. 22.05.2003 ; опубл. 16.02.2004, бюл. № 2.

23. Развязкина Г. М. Упрощенный метод обнаружения в электронном микроскопе вирусных частиц из сока растений / Г. М. Развязкина, Г. П. Полякова, В. А. Штейн-Марголина // Вопр. вирусол. - 1968. - № 5. - С. 633-934.

24. Лабораторний практикум з загальної фітовірусології : [навчальний посібник] / М. Д. Мельничук, В. С. Кожукало, С. О. Смірнова, Г. Г. Мартин. - К. : НАУ, 2002. - 260 с.

25. Радкович Е. В. Изучение различных схем иммунизации лабораторных животных для получения специфических антисыровоток к вирусам картофеля / Е. В. Радкович, Г. Н. Гуща, И. В. Филонова // Картофелеводство : сб. науч. тр. Минск, 2008. - Т. 14. - С. 409-416.

26. Дунин М. С. Капельный метод анализа вирусов в растениеводстве / М. С. Дунин, Н. М. Попова. - М. : Сельхозгиз, 1937. — 47 с. 


\section{ХАРАКТЕРИСТИКА ІЗОЛЯТУ ВІРУСУ ЖОВТОЇ МОЗАЇКИ КВАСОЛІ, ВИДІ- ЛЕНОГО 3 ЛЮПИНУ ЖОВТОГО}

\section{О. В. Пиріг, О. О. Дмитрук, Т. О. Бова}

Інститут сільськогосподарської мікробіології та агропромислового виробництва НААН, м. Чернігів

Представлено порівняльну характеристику біологічних, фізико-хімічних $і$ антигенних властивостей ізоляту вірусу жовтої мозаїки квасолі (ВЖМК-П), виділеного з люпину жовтого на території Чернігівської області. Встановлено, щчо за своӥми властивостями ізолят ВЖМК-П відрізнясться від властивостей типового итаму ВЖМК (B-25) та ізолятів, виділених і вивчених в Украӥні.

Ключові слова: люпин жовтий, вірус жовтої мозаїки квасолі (ВЖМК), ізолят, антисироватка.

\section{ХАРАКТЕРИСТИКА ИЗОЛЯТА ВИРУ- СА ЖЁЛТОЙ МОЗАИКИ ФАСОЛИ ВЫ- ДЕЛЕННОГО ИЗ ЛЮПИНА ЖЕЛТОГО}

\author{
А. В. Пирог, О. А. Дмитрук, Т. А. Бова
}

Институт сельскохозяйственной микробиологии и агропромышленного производства НААН, г. Чернигов

Представлена сравнительная характеристика биологических, физико-химических и антигенных свойств изолята вируса жёлтой мозаики фасоли (ВЖМК-П), выделенного из люпина жёлтого на территории Черниговской области. Установлено, что по своим свойствам изолят ВЖМК-П отличается от свойств типичного штамла ВЖМК (B-25) и изолятов, выделенных и изученных в Украине.

Ключевые слова: люпин жёлтый, вирус жёлтой мозаики фасоли (ВЖМФ), изолят, антисыворотка. 